\title{
Corporate Reputation And Social Responsibility: An Analysis Of Large Companies In Croatia
}

Neda Vitezić, University of Rijeka, Croatia

\begin{abstract}
This paper aims to explore the relationship between corporate reputation and social responsibility $(C S R)$ in selected large Croatian companies. The research is based on the theoretical framework that supports a thesis of their positive relationship. CSR is measured through economic, environmental, and social aspects and is primarily based on testing the relationship between CSR and financial performance to determine whether the relationship is positive, neutral or negative. Many researchers have concluded that it is generally positive, depending on which measures of financial performance are used. At the same time, corporate reputation is considered as a key mediator in the relationship between a firm's CSR and financial performance. In this concept of CSR, reputation is a "global perception» of a group of stakeholders, its «assessment of the credibility of the organization's projection». Company reputations may vary from one stakeholder to another depending of their expectations, which are dynamic and likely to change over time. It is within this context of company relationships with its stakeholders that determines the level of reputation a company will develop over time. Thus corporate reputation will be directly and significantly related to CSR. Based on this hypothesis, they are a few objectives of this research. The first is to analyze the significance of the proposed corporate attributes according to company and customer perspective. For that purpose, seven practical and theoretical background attributes are selected and ranked - quality of products and services, corporate vision and strategy, quality of management leadership, labor force, financial performance, social and environmental responsibility, and corporate governance. Second is to propose indicators for each reputation attribute and rank them according to their significance collected by surveying large companies' executives. Third is to analyze the correlation between socially responsible companies and their reputation. The research results show that one of the corporate attributes - CSR - is ranked very low from the point of view of company executives and employees, but very high from the perspective of consumers. Among the indicators which represent socially responsible performance, financial performance is ranked first, followed by ecological and social performance. A positive relationship between financial performance and corporate reputation has been statistically confirmed; i.e., socially responsible Croatian large companies have better financial results measured by ROA, ROE, margin profit and EPS.
\end{abstract}

Keywords: CSR; corporate reputation; Croatian large companies

\section{INTRODUCTION}

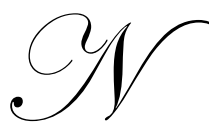

owadays, after financial turmoil and crises which have characterized the first decade of the 21 st century, many companies focus on regaining the trust of a great number of stakeholders. Most stakeholders have been globally experiencing a crisis of confidence, and this especially refers to mistrust of buyers. This situation primarily reflects on the company's reputation, which should be protected in terms of invisible but very valuable assets. One of the quick solutions for protection of reputation is also corporate governance, as well as social responsibility issues. Corporate governance is a broad concept where responsibility and transparent reporting are the two main principles. They are incorporated in the social responsibility concept 
which stresses responsibility (accountability) toward all stakeholders, as well as public announcing of company's responsible performance. This is why, in the process of defining reputation and its conceptualization, the starting point is the company's degree of responsibility in the decision-making process which influences a certain group of stakeholders. Meeting the expectations of stakeholders directly contributes to corporate reputation which may be expressed by various attributes.

Many researchers throughout the world elaborate on the concept of corporate social responsibility and its derivative - social performance - by connecting it with financial performance, added value, marketing, public relation issues, etc. However, the issue, which has been subject to theoretical and empirical research for a long time, is whether CSR has any impact on reputation; i.e., whether corporate social performance concept is accepted for reasons of improvement of company's reputation on the market and whether it also generates greater financial effects; i.e., whether there is a direct connection between corporate social performance and reputation, as well as whether there is a positive correlation between financial business activities and reputation (Neville, B.A. at all., 2005,p.1191). Research results differ and most results indicate that reputation plays a key role in the CSR and financial performance relationship.

Emerging countries, such as Croatia, try to keep up with the developed countries and, in this sense, accept the principles and recommendations of the developed countries referring to corporate governance and social responsibility requirements. Almost all large companies, especially those with a developed brand, accept the principles of corporate management and social responsibility. Reporting recommendations are also accepted, and social responsibility indicators are developed and included in annual reports.

Reporting is mostly conducted according to Global Reporting Initiative (GRI) guidelines which are presented as a separate CSR Report or included in the Annual Report. These reports include quantitative and qualitative indicators according to the "triple bottom line" concept; i.e., the concept which comprises economic, environmental and social bottom line.

There is no current research on the relationship between corporate social responsibility and its impact on the reputation of Croatian companies. Thus, the main goal of this research is to investigate whether there is some existing correlation. To answer this complex question, literature was reviewed first, and reputation attributes were selected accordingly. What follows is an explanation of the survey method, analysis, and the results and limitation of the research are presented in the end.

\section{LITERATURE REVIEW}

"If corporate social responsibility, as it is understood and managed today, was about enhancing reputation, companies would have stopped doing it by now because it doesn't work" pointed out Griffin in his book Reputation Management (Griffin, A. 2008, p. 144). He explains that companies are somewhat afraid of the CSR concept, which could someday turn to lawsuits. Moreover, CSR is not a new concept because companies have been implementing it for a long time. The point of emphasis is the fact that CSR is not the vehicle for companies to prove that they are good!! CSR, as a concept, integrates social and environmental concerns in the company performance and its interaction with stakeholders on voluntary bases (European Commission's Green Paper, 2001). It is the integration of financial, environmental and social performance into the "triple bottom line" reporting system that is used mostly as a tool in order to demonstrate company's good citizenship. That helps them to increase revenues and profitability, return money to shareholders and, at the same time, gain reputation. This statement is constantly under review by many researchers and it has still not been confirmed whether CSR is, ultimately, just a "new tool" for earning profit, or whether companies are truly aware of the responsibility to the society and the environment. Unfortunately, there are examples of large multinational companies which claim to be highly responsible, but nevertheless disregard some of the aspects of responsibility when it comes to profit (Nokia's chairman has been accused of being a "job killer" who puts profit measures of a few before the well-being of many). Likewise, it is difficult to assess true benefits of philanthropy to those whom donations or sponsorships - charitable donations - are earmarked for. Some researchers (Williams and Barrett, 2000) provide recent evidence in support of a positive link between philanthropy and corporate reputation. However, it is indisputable whether a company increases its reputation by giving donations to the social community, individuals, etc., and this includes possible savings (no worries about waste disposal). On 
the other hand, some researchers argue that CSR orientation increases company costs and decreases stakeholders' profit (Friedman, 1970).

According to past and recent research, it is quite clear that corporate reputation significantly contributes to long-term competitive advantages of organizations, and that is its strategic success factor. Reputation is not easy to define because it depends on various stakeholders' views, intentions and expectations of enterprise performance. Stakeholders, especially investors and suppliers, would see enterprise reputation from a different angle than the customers. Although both are directly involved, customers are focused on quality and included business partners and suppliers mostly assess financial and overall business performance. In this sense, reputation could be defined from the aspect of creditworthiness when they are synonymous. From the customers' points of view, CSR "positively influences customer satisfaction and loyalty within consumer segments" (Helm, S. 2007, p.238 Sarstedt, M., et al, 2008, p. 27). All other stakeholders - secondary group (media, syndicate, community etc.) - will estimate from the overall perception oriented mostly to social and environmental interests. Weiss et al (1999, p. 75) defined corporate reputation as "a global perception of the extent to which an organization is held in high esteem or regard." Professor Stephen A. Greyser of the Harvard Business School states that "corporate reputation is a window to the fundamental character of a company and its leaders and, as such, is relevant to all stakeholders." From the shareholders' points of view, reputation stands for a valuable asset; i.e., "intangible resource which may provide the organization with a basis for sustaining competitive advantage given its valuable and hard-to-imitate characteristics" (Hall, 1993; Barney, 1991). Shareholders very often identify reputation with financial position and possibility to gain profitable return. This is why emphasis in literature (Roberts and Dowling, 2002; Eberl and Schwaiger, 2005; Rose and Thomsen, 2004; and Inglis, Morley, Sammut, 2006) is often placed on enterprise reputation as a valuable resource as well as its association with financial performance. Good reputation could increase sales or revenue and reduce operating costs; thus, reputation is viewed from the aspect of financial benefits and is directed through reputation financial performance relationship. Besides this relationship, it was found that financial performance affects reputation (Rose and Thomsen, 2004, p.208), so we could talk about a "reputational vicious circle". In that case, motivation to accept social performance as one of the reputation determinants could be related to the outcomes of financial gains.

Reputation, in a broader sense, could be defined as "a perceptual representation of a company's past actions and future prospects that describes the firm's overall appeal to all its key constituents when compared to other leading rivals" (Fombrun, 1996, p. 72). The same author has, in co-operation with others, constructed a definition of reputation relating to various fields - economics, strategy, marketing, organisation theory, sociology, communication, and accounting. In relation to this construction, authors suggested that corporate reputation is a "collective construct that describes the aggregate perception of multiple stakeholders about a company's performance" (Fombrun, C., Gardberg, N. and Sever, J., 2000, p. 243). This confirms the statement that reputation is hard to define, precisely because it depends on the perception of stakeholders. Except for this complexity, it should be taken into consideration that companies differ according to their size, business activity, structure, management and leadership, social performance, etc. For example, heavy industry is more closely linked with some type of environmental and social issues than newer manufacturing industries or the services sector. For that reason, Brammer and Pavelin (2004) proposed that distinction between types of business activities and social performance plays an important role in defining of the relationship between social performance and corporate reputation.

\section{REPUTATION DIMENSIONS}

As an intangible valuable asset, reputation should mostly be measured by qualitative measures. Nowadays, after so many financial scandals, accounting information and measurement are not very reliable and are insufficient for the holistic approach to corporate performance. More and more researchers and practitioners emphasise nonfinancial measurement instruments as more reliable means for overall assessment of corporate performance and its reputation. Reputation, as valuable intangible assets, could not be judged only by financial performance, although some researchers argue that financial performance has a positive influence on reputation; i.e., it was found that financial performance affects reputation (Rose and Thomsen, 2004, p. 208). Reputation is a much broader concept and deserves to be estimated by qualitative and quantitative (financial and non-financial) indicators. 
Reputation, as a multidimensional concept, has been identified as an objective in many surveys from the early 80 's. Some surveys started to construct measurement systems which would be applicable in practice. Each research, like the one in the Fortune AMAC (America's Most Admired Companies), Manager magazines (Germany), Management Today (Britain's Most Admired Companies - BMAC), Asian Business (AB- Asia's Most Admired Companies), Far Eastern Economic Review (Asia's Leading Companies), Financial Times (European's Most Respected Companies) and, finally, Fortune GMAC (The Global Most Admired Companies), came to the conclusion about reputation attributes; i.e., measure. There is a difference between them, but common attributes have been established, such as quality of management, quality of products and services, financial soundness, responsibility to the community and environment, and innovativeness. Most surveys are based on the experience of large companies and limited industries, as well as limited respondents - mostly managerial staff.

For a number of years, academics mostly use Fortune's annual corporate reputation index, which is based on research carried out among some 10,000 senior executives in the USA who are asked to rate the ten largest companies in their industry. They found eight significant attributes (AMAC, 2008): 1) ability to attract and retain talented people, 2) quality of management, 3) quality of products or services, 4) innovativeness, 5) long-term investment value, 6) financial soundness, 7) wise use of corporate assets, and 8) social responsibility to the community and the environment.

Except for these eight attributes, the WMAC Fortune (2010) added a ninth attribute - effectiveness in conducting business globally. Britain's Most Admired Companies - BMAC (2010) emphasised almost the same attributes as Fortune while making distinctions between the "quality of marketing" and "value as a long-term investment".

Some criticize that most indicators are influenced by the ratters' perception of the financial potential of the firm and that index measured little beyond performance (Caruna, 1997 p. 109.)

Australia's Repu Tex (2006) bases their index on four dimensions - corporate governance, workplace practices, social impact, and environmental impact.

Some researchers criticize the existing reputation measurement system and propose some other dimensions. For example, Groenland (2002) proposes the use of a "reputation quotient" (RQ) which encompasses six dimensions: 1) emotional appeal, 2) product and services, 3) vision and leadership, 4) workplace environment, 5) social and environmental responsibility, and 6) financial performance. The Annual RQ Survey measures reputations of the 60 most visible companies, as well as other companies, representing major industries in the US.

Corporate reputation index does not exist in Croatia, but measurement of socially responsible companies by means of index does. In 1997, the Croatian Business Council for Sustainability was founded as a member of World Organization for Sustainability, which also includes a few organizations within the Chamber of Commerce and the Croatian Employers' Association, as well as other professional and advisory organizations and government institutions and public agencies. Civil society organizations have also been included in the CSR-related activities. The Code of Ethics was established in 2007 and the Corporate Governance Code is obligatory for all companies on the trade market. The social responsibility concept has an impact on business activities of organizations, and almost all branded large companies have developed a measurement system, mostly according to the Global Reporting Initiatives framework.

Based on recent literature mentioned above, and according to the behaviour of Croatian organizations and the overall business situation, corporate reputation attributes were selected for the purpose of this research. The most important seven attributes are: 1) quality of products and services, 2) corporate vision and strategy, 3) quality of management - leadership, 4) labour forces, 5) financial performance, 6) social and environment responsibility, and 7) corporate governance.

Quality of products and services is surely the most important attribute of reputation, especially from the customer's point of view. Being a good producer depends on the quality of management; i.e., leadership, the set vision and strategy and particularly on labour forces as the most important factor which has knowledge, skills and 
innovative ideas. Profitable performance is one of the first company goals and financial effectiveness is one of the factors which stimulates and supports a company in the implementation of social performance. Corporate governance is added as a broad concept of controlled organizational mechanisms that help to govern management behaviour in the direction of socially responsible performance.

\section{RESEARCH METHODOLOGY AND RESULTS}

\section{Method and Data}

This study is the beginning of a survey on the perception of Croatian corporate social responsibility and its impact on corporate reputation. Research is based on the statement that reputation is holistic perception of corporate image and global assessment of all stakeholders about overall enterprise performance and behaviour. Thus, research should be oriented on different groups of stakeholders and their perception of reputation attributes. The majority of attributes in recent literature is defined according to a single group of stakeholders - management or executives.

In this research, a questionnaire was sent to chief executives, owners, and other employees who represent one group, and to the customers who represent another group of stakeholders. The total sample included 192 representatives. Both groups were randomly selected, regardless of their company size, business activity or customer types. They were asked to grade each of the attributes of reputation according to their perception. Secondly, a possible measure was proposed based on the ranking results for each of the selected reputation attributes. This questionnaire was sent only to the socially responsible companies - 20 large firms from different sectors that have the CSR reporting system available by internet. Their chief executives and financial analysts were asked (personal interviews) to rank each of the proposed indicators based on their opinion on its importance for reputation assessment. Finally, the correlation between social responsibility and corporate reputation was examined by in-depth qualitative analysis and the univariate method. For this purpose, another 20 large companies, who have not developed a corporate social responsibility reporting system, were randomly selected no matter of their industry type. In Croatia, large companies represent 0.5 percent of the total number of companies, thus the sample represents 9.2 percent of them and offers a solid research database.

\section{Survey Analysis and Results}

The aim of this research is to investigate whether there is a relationship between corporate social responsibility and reputation assessment in Croatian large branded companies. More specifically, do corporate social performance and the CSR measurement system influence a higher reputation of specific enterprises? Recent literature suggests that both directions do exist considering interrelation between reputation and socially-oriented performance; i.e., the impact of reputation on performance and the impact of performance on reputation. The set hypothesis is as follows:

H1: There is a positive relationship between corporate social responsibility and reputation.

In order to confirm the set hypothesis, attributes of reputation are analysed first for the purpose of determining their significance. A questionnaire was sent to two different groups of stakeholders - customers (various public consumers) and company representatives (executives, owners, and other employees' profile). The questionnaire was sent by E-mail, communicated by telephone, or by personal interview. The total sample included 192 answers -82 by company representatives (executives and non-executives) and 110 by various consumers. The aim of this questionnaire was to investigate the significance of each reputation attribute from the aspect of the company and from various consumers. The participants were asked to rate each of the reputation attributes on a scale of 1 (the highest) to 7 (the lowest) for the following reputation components. Table 1 shows the significance of each proposed reputation attribute from the company and customer perspectives. 
Table 1: Attributes of Reputation

\begin{tabular}{|c|l|c|c|c|c|}
\hline & & \multicolumn{3}{|c|}{$\begin{array}{c}\text { Ranking from } \\
\text { Company Perspective }\end{array}$} & $\begin{array}{c}\text { Ranking from } \\
\text { Customer Perspective }\end{array}$ \\
\cline { 3 - 5 } No. & \multicolumn{1}{|c|}{ Reputation Attributes } & $\mathrm{E}=60$ & $\mathrm{NE}=22$ & $\mathrm{~N}=82$ & $\mathrm{~N}=110$ \\
\hline 1. & Quality of products and services & 1 & 1 & 1 & 1 \\
\hline 2. & Corporate vision and strategy & 3 & 5 & 3 & 4 \\
\hline 3. & Quality of management -Leadership & 4 & 2 & 4 & 5 \\
\hline 4. & Labour forces & 2 & 3 & 2 & 6 \\
\hline 5. & Financial performance & 5 & 2 & 5 & 2 \\
\hline 6. & Corporate Social Responsibility & 7 & 6 & 6 & 7 \\
\hline 7. & Corporate Governance & 6 & 7 & 7 & \\
\hline
\end{tabular}

Source: Survey

Legend:

$\mathrm{E}=$ executives $\quad \mathrm{NE}=$ non-executives $\quad \mathrm{N}=$ total sample

The results show that, in the ranking of reputation attributes, quality of products and services is the most important for the selected group of stakeholders as well as the consumers. From the company's perspective, owners and management ranked labor forces in second place and corporate vision and strategy in third place. However, employees believe that management quality and financial performance quality are the most important attributes. This indicates that employees believe that leadership has an influence on financial performance, on which their salaries also depend.

However, the most interesting fact is that both CSR and CG are ranked last, which implies that examinees do not consider them primary in Croatian conditions where large companies cope with financial sustainability problems. It is to be assumed that some of the examinees have not been introduced to the meaning of Corporate Governance. From the customer's perspective, attributes of reputation are ranked quite differently. After the quality of products and services in the first place, CSR takes second place. However, from the consumers' aspect, reputation attributes rank completely different because social responsibility takes second place, after the quality of products and services. Such ranking indicates high consumer awareness on ecological and social aspects, awareness and care for their health, and probably willingness to support such an orientation, regardless of the price. From their point of view, financial performance and CG do not have significant influence on reputation.

The next research objective, which would prove the relationship between CSR and reputation, was to examine CSR and reputation on the sample of 20 large companies in Croatia. The sample consisted of companies that published reports on CSR, which included indicators based on the"triple bottom line concept" (economic, ecological and social aspects of business activities).

Appropriate indicators have been suggested for each reputation attribute, which were also to be ranked from 1 (the highest rank) onwards. It is difficult to measure reputation through the selected indicators, primarily because every stakeholder has one's own perception of reputation and, therefore, one's own measures which are mostly expressed quantitatively. Secondly, qualitative research methods are needed for in-depth analysis of individual perception of reputation. Thirdly, there is a connection between indicators; i.e., quantity affects quality and vice versa, such as "better leadership will influence better performance and better financial results will enable more philanthropy activities". For reasons of the mentioned limitations, only some indicators - mostly quantitative ones - are suggested, although it should be emphasized that qualitative expression is characteristic for most reputation attributes. Based on an interview and questionnaire survey, Table 2 shows the ranked indicators for each of the proposed attributes. 
Table 2: Measuring of Reputation Attributes by Indicators and Their Significance

\begin{tabular}{|c|c|c|}
\hline No. & Attributes & Ranked Indicators \\
\hline 1. & Quality of products and services & $\begin{array}{ll}\mathbf{2} & \text { existence of product brand } \\
\mathbf{3} & \text { number of quality awards } \\
\mathbf{1} & \text { market share } \\
\end{array}$ \\
\hline 2. & Company vision and strategy & $\begin{array}{ll}\mathbf{1} & \text { clearly defined vision } \\
\mathbf{2} & \text { existence of strategic and operative plans } \\
\mathbf{3} & \text { existence of BSC }\end{array}$ \\
\hline 3. & Quality of management -Leadership & $\begin{array}{ll}\mathbf{3} & \text { time spent on managerial position } \\
\mathbf{4} & \text { number of awards } \\
\mathbf{1} & \text { positive business financial results (number of years) } \\
\mathbf{2} & \text { percentage of fluctuation } \\
\end{array}$ \\
\hline 4. & Work force (Employees) & $\begin{array}{ll}3 & \text { increased number of employees } \\
\mathbf{1} & \text { rise in salary } \\
\mathbf{2} & \text { percentage of resources intended for education } \\
\mathbf{5} & \text { number of labor disputes } \\
\mathbf{4} & \text { percentage of resources for other intentions } \\
& \text { (hot meal, protection at work place...) regarding to total costs }\end{array}$ \\
\hline 5. & Financial performance & $\begin{array}{ll}4 & \text { increase of sales quantity } \\
\mathbf{1} & \text { increase of profitability (ROA, ROE...) } \\
\mathbf{2} & \text { increase of value added } \\
\mathbf{3} & \text { increase of investments } \\
\mathbf{6} & \text { increase of share price } \\
\mathbf{5} & \text { operative cash-flow }\end{array}$ \\
\hline 6. & Corporate Social Responsibility & $\begin{array}{ll}\mathbf{2} & \text { number of ecological responsibility indicators } \\
\mathbf{3} & \text { number of social responsibility indicators } \\
\mathbf{1} & \text { number of positive financial indicators } \\
\end{array}$ \\
\hline 7. & Corporate Governance & $\begin{array}{ll}\mathbf{2} & \text { existence of Corporate Governance Code } \\
\mathbf{3} & \text { existence of Audit and Ethics Committee } \\
\mathbf{1} & \text { transparency in reporting (annual reports) } \\
\end{array}$ \\
\hline
\end{tabular}

Source: Survey

The analysis of results and ranking of certain indicators has shown that the most significant indicator is the quality of products and services and the most important measure is market share. A clearly defined vision, elaborated plans, and BSC model have confirmed the company vision and strategy attribute. From the aspect of leadership, the primary indicator is related to positive financial results and work force fluctuation. Rise in salary and the percentage of resources earmarked for education are the primary attributes for the labor force. The most common measures of financial performance are profitability increase measured by the ROA, ROE and increase in added value.

Taking into consideration that the research goal was to examine the influence of CSR on company reputation; that is, to confirm whether there is a positive relationship between them, the focus was on the given rank of CSR and CG indicators. Namely, companies that declare themselves socially responsible rank positive financial performance within the CSR attribute first, ecological aspects second, and social aspects third. Likewise, transparent annual reporting and existence of a Code are the most important CG indicators.

Survey results indicate that economical (financial) business aspect was the most important in the evaluation of social responsibility, thus the subject of analysis was whether there is a correlation between financial performance and CSR. For this purpose, the following hypothesis was set:

H2: Positive relationship between company's financial performance and corporate social responsibility will strengthen corporate reputation

For this purpose, the realized financial results of socially responsible companies (20 on average) were compared with the results of companies that did not publish CSR reports ( 15 on average). The survey was conducted for the period 2004 to 2009 (six years) on a sample of 35 large companies (total of 40). Tables 3, 4 and 5 reflect the results. 
Table 3: Descriptive Statistics for the Total Sample

\begin{tabular}{|l|c|c|c|c|c|c|}
\hline & N & Minimum & Maximum & Sum & Mean & Std. Deviation \\
\hline ROA & 209 &,- 2391 &, 3544 & 9,0953 &, 043518 &, 0747286 \\
\hline ROE & 208 &,- 6329 &, 6008 & 17,2452 &, 082910 &, 1315407 \\
\hline MP & 209 &,- 8190 &, 6147 & 10,9142 &, 052221 &, 1186734 \\
\hline EPS & 166 & -216 & 1783 & 19045 & 114,73 & 229,840 \\
\hline PPS_R & 126 & 10 & 24117 & 173468 & 1376,73 & 3036,966 \\
\hline Valid N (listwise) & 102 & & & & & \\
\hline
\end{tabular}

Legend:

ROA=return on assets $\quad$ ROE=return on equity $\quad \mathrm{MP}=$ margin profit $\quad$ EPS $=$ earnings per share

$\mathrm{PPS}=$ price per regular share

Table 4: Descriptive Statistics for CSR Companies

\begin{tabular}{|l|c|c|c|c|c|c|}
\hline & N & Minimum & Maximum & Sum & Mean & Std. Deviation \\
\hline ROA & 120 &,- 2391 &, 3544 & 7,9872 &, 066560 &, 0790419 \\
\hline ROE & 120 &,- 6329 &, 6008 & 15,0502 &, 125419 &, 1422443 \\
\hline MP & 120 &,- 8190 &, 5052 & 9,1152 &, 075960 &, 1302217 \\
\hline EPS & 89 & -110 & 1783 & 12942 & 145,42 & 258,894 \\
\hline PPS_R & 67 & 50 & 24117 & 93710 & 1398,65 & 3338,994 \\
\hline Valid N (listwise) & 53 & & & & & \\
\hline
\end{tabular}

Source: Survey

Legend:

ROA=return on assets $\quad$ ROE=return on equity $\quad$ MP- margin profit $\quad$ EPS- earnings per share

PPS-price per regular share

Table 5: Descriptive Statistics for Companies that Lack Social Responsibility

\begin{tabular}{|l|c|c|c|c|c|c|}
\hline & N & Minimum & Maximum & Sum & Mean & Std. Deviation \\
\hline ROA & 89 &,- 1822 &, 2902 & 1,1080 &, 012450 &, 0552331 \\
\hline ROE & 88 &,- 3126 &, 4513 & 2,1950 &, 024943 &, 0871912 \\
\hline MP & 89 &,- 2761 &, 6147 & 1,7990 &, 020214 &, 0924773 \\
\hline EPS & 77 & -216 & 975 & 6103 & 79,25 & 186,284 \\
\hline PPS_R & 59 & 10 & 14350 & 79759 & 1351,84 & 2681,353 \\
\hline Valid N (listwise) & 49 & & & & & \\
\hline
\end{tabular}

Source: Survey

Legend:

ROA=return on assets $\quad$ ROE=return on equity $\quad$ MP- margin profit $\quad$ EPS- earnings per share

PPS-price per regular share

Financial performance was measured by common indicators used in similar research; i.e., profitability was measured by ROA, ROE, margin profit and shares value. Average values of these indicators significantly deviate in companies that have CSR reports; for example, the average ROA is $6.7 \%$ with corresponding standard deviation of $7.9 \%$ and average ROE of $12.45 \%$ (St. dev. 14.2 percent). At the same time, in companies that have not published reports on CSR, ROA is $1.32 \%$ with corresponding standard deviation of $5.5 \%$ and average ROE of $2.5 \%$ (St. dev. $8.7 \%$ ), respectively. This research has also confirmed the hypothesis expressed in other research, which is that CSR has an influence on financial performance of a company. The difference between means is statistically significant at $1 \%$ level, which confirms the set hypothesis. An Independent Sample Test (T-test) was conducted and the results are shown in Table 6. 
Table 6: Independent Samples Test (T-test)

\begin{tabular}{|c|c|c|c|c|c|c|c|c|c|c|}
\hline \multicolumn{11}{|c|}{ Independent Samples Test } \\
\hline & & $\begin{array}{r}\text { Levene's } \\
\text { Equality of }\end{array}$ & $\begin{array}{l}\text { st for } \\
\text { ariances }\end{array}$ & \multirow[b]{3}{*}{$t$} & \multirow[b]{3}{*}{ df } & \multicolumn{3}{|c|}{ t-test for Equality of Means } & \multirow{2}{*}{\multicolumn{2}{|c|}{$\begin{array}{l}95 \% \text { Confidence } \\
\text { Interv al of the } \\
\text { Dif f erence }\end{array}$}} \\
\hline & & \multirow{2}{*}{$x_{1}$} & \multirow[b]{2}{*}{ Sig. } & & & & Mean & Std. Error & & \\
\hline & & & & & & Sig. (2-tailed) & Dif $f$ erence & Dif $f$ erence & Lower & Upper \\
\hline $\mathrm{ROA}$ & $\begin{array}{l}\text { Equal variances } \\
\text { assumed } \\
\text { Equal variances } \\
\text { not assumed }\end{array}$ & 10,557 &, 001 & $\begin{array}{l}5,532 \\
5,823\end{array}$ & $\begin{array}{r}207 \\
206,332\end{array}$ & $\begin{array}{l}, 000 \\
, 000\end{array}$ & $\begin{array}{l}, 0541104 \\
, 0541104\end{array}$ & $\begin{array}{l}, 0097809 \\
, 0092920\end{array}$ & $\begin{array}{l}, 0348276 \\
, 0357910\end{array}$ & $\begin{array}{l}, 0733933 \\
, 0724299\end{array}$ \\
\hline ROE & $\begin{array}{l}\text { Equal variances } \\
\text { assumed } \\
\text { Equal variances } \\
\text { not assumed }\end{array}$ & 11,010 &, 001 & $\begin{array}{l}5,865 \\
6,292\end{array}$ & $\begin{array}{r}206 \\
200,270\end{array}$ & $\begin{array}{l}, 000 \\
, 000\end{array}$ & $\begin{array}{l}, 1004759 \\
, 1004759\end{array}$ & $\begin{array}{l}, 0171308 \\
, 0159688\end{array}$ & $\begin{array}{l}, 0667017 \\
, 0689874\end{array}$ & $\begin{array}{r}, 1342500 \\
, 1319644\end{array}$ \\
\hline MP & $\begin{array}{l}\text { Equal variances } \\
\text { assumed } \\
\text { Equal variances } \\
\text { not assumed }\end{array}$ & 6,299 &, 013 & $\begin{array}{l}3,445 \\
3,618\end{array}$ & $\begin{array}{r}207 \\
206,649\end{array}$ & $\begin{array}{l}, 001 \\
, 000\end{array}$ & $\begin{array}{l}, 0557458 \\
, 0557458\end{array}$ & $\begin{array}{l}, 0161840 \\
, 0154079\end{array}$ & $\begin{array}{l}, 0238393 \\
, 0253689\end{array}$ & $\begin{array}{l}, 0876524 \\
, 0861227\end{array}$ \\
\hline EPS & $\begin{array}{l}\text { Equal variances } \\
\text { assumed } \\
\text { Equal variances } \\
\text { not assumed }\end{array}$ & 2,358 & ,127 & $\begin{array}{l}1,863 \\
1,907\end{array}$ & $\begin{array}{r}164 \\
158,934\end{array}$ & $\begin{array}{l}, 064 \\
, 058\end{array}$ & $\begin{array}{l}66,163 \\
66,163\end{array}$ & $\begin{array}{l}35,507 \\
34,695\end{array}$ & $\begin{array}{l}-3,946 \\
-2,360\end{array}$ & $\begin{array}{r}136,272 \\
134,687\end{array}$ \\
\hline PPS_R & $\begin{array}{l}\text { Equal variances } \\
\text { assumed } \\
\text { Equal variances } \\
\text { not assumed }\end{array}$ &, 001 & ,970 & $\begin{array}{l}, 086 \\
, 087\end{array}$ & $\begin{array}{r}124 \\
122,999\end{array}$ & $\begin{array}{l}, 932 \\
, 931\end{array}$ & $\begin{array}{l}46,812 \\
46,812\end{array}$ & $\begin{array}{l}544,368 \\
536,898\end{array}$ & $\begin{array}{l}-1030,646 \\
-1015,945\end{array}$ & $\begin{array}{r}1124,270 \\
1109,569\end{array}$ \\
\hline
\end{tabular}

Finally, based on the entire research and in-depth analysis, it is confirmed that 20 large companies that have, in the survey, confirmed their ranks by particular reputation indicators, transparently report on these issues in their CSR reports. They report increased profitability and better business results, allocation of resources for employees' education, protection at work, take care of representation of managerial positions, etc., women are represented on the managerial functions and so on. They also donate funds, take sponsorships, co-operate with scientific institutions and implement quality and environment management systems, report on greenhouse gas emissions, toxic waste quantity and other pollutions, energy consumption and investments in renewable energy sources. Qualitative analyses have verified that CSR also has an influence on reputation, which is a key mediator in the relationship between a company's CSR and its financial performance.

\section{CONCLUSION}

Corporate reputation is a strategic success factor and thus deserves attention in a complex business environment. A developed measurement system and reputation index does not exist in Croatia. Therfore, this research provides a certain contribution because significance of individual reputation attributes was established on the sample of 20 large companies. From the suggested seven, all examinees (direct stakeholders, owners, management, employees, and various customers) ranked quality of products first. From the company aspect (owners, executives, and employees), the first three attributes are quality of products or services, labor forces, and corporate vision and strategy. From the customers' point of view, quality of products and services is the most important, followed by corporate social responsibility and labor forces. The obtained research results indicate that the starting point in the holistic assessment of reputation will be individual opinions and that estimation cannot be expressed simply and synthetically. Since financial constituent is the easiest to measure, it is the most frequent tool for establishing the correlation with reputation and the CSR. The sample of Croatian large companies included in this research shows, as well as results from most other research, that socially responsible companies, which also report on social responsibility, also have better financial performance. Thus, CSR may be considered one of the important reputation attributes, especially from the aspect of customers. In-depth analysis of certain reputation attributes has confirmed that socially responsible companies rank certain reputation elements which they develop at the same time. Thus, it can be concluded that there is a positive correlation between socially responsible business activities and reputation. 


\section{LIMITATION OF THE RESEARCH}

Reputation depends on stakeholders' opinions, and all groups of stakeholders should therefore be included in its estimation. This research was limited to owners, management, employees, and customers; and for that reason, it does not validly represent a holistic approach to corporate reputation. Proposed measures for each of the selected reputation attributes are quantitative and qualitative, some of which are difficult to express by indicators. Thus, there is a need for extensive research in order to find exact and adequate measures and measurement system which would provide an improved expression of a specific attribute.

\section{AUTHOR INFORMATION}

Neda Vitezić, CPA, CIA is professor of Accounting, specialisation Business Analysis, Controlling and Auditing in the School of Economics University of Rijeka, Croatia. She has over 30 years experience as professor and practioner in the field of accounting, finance and entrepreneurship, and is visiting professor in Slovenia, England and USA. She published a book named Auditing and Business analysis and over 120 articles in journals and proceedings. Her current research interests are corporate social responsibility and their impact to firms' performance and reputation Today she is a leading MBA Controlling. E-mail: nevit@efri.hr

\section{REFERENCES}

1. Barney, J. (1991), Firm resources and sustainable competitive advantage, Journal of Management, Vol.17, pp. $99-120$

2. Caruna, A.(1997), Corporate reputation: concept and measurement, Journal of Product \& Brand Management, Vol. 6 No.2 pp. 109-118.

3. Eberl, M., Schwaiger, M, (2005), Corporate reputation: disentangling the effects on financial performance, European Journal of Marketing, Vol.39 No 7/8, pp.834-54.

4. Elkington, J. (1997), Canibal with Forks: The Triple Bottom Line of 21st Century Business, Capstone, Oxford.

5. Fombrun, C. (1996), Reputation: Realizing Value from the Corporate Image, Harvard Business School Press, Boston, MA.

Fombrun, C., Gardberg, N. and Sever, J. (2000) The reputation quotient SM: A multi-stakeholders measure of corporate reputation, The Journal of Brand Management, 7, 241-255.

6. Freeman, R.E. (1984), Strategic Management: A Stakeholder Approach, Pitman Publishing, Boston, MA.

7. Friedman, M.,(1970), The social responsibility of business is to increase its profit, New York Times Magazine, pp.122-6.

8. Griffin, A. (2008): Reputation Management: Gaining control of Issues, Crisis \& Corporate Social Responsibility, Kogan Page Limited, UK and USA

9. Hall, R. (1993), "A framework linking intangible resources and capabilities to sustainable competitive advantage", Strategic Management Journal, Vol.14, pp.607-618

10. Helm, S. (2007), One reputation or many? Comparing stakeholders' perception of corporate reputation, Corporate Communications: An International Journal 12(3), pp. 238-254.

11. Inglis, R. Morley, C., Sammut, P., (2006), Corporate reputation and organisational performance: an Australian study, Managerial Auditing Journal, Vol.21 No 9. pp. 934-947.

12. Neville, B. A., Bell, S. J., Mengüc, B.(2005), Corporate reputation, stakeholders and the social performance-financial performance relationship, European Journal of Marketing, Vol39,No. 9/10, pp.1184-1196.

13. Resnick, J. T. (2004), Corporate reputation: Managing corporate reputation-applying rigorous measures to a key asset, Journal of Business Strategy, Vol.5No6,pp.30-38

14. Rose, C. and Thomsen, S. (2004), The impact of corporate reputation on performance: some Danish evidence, European Management Journal, Vol.22 No.2, pp.201-210.

15. Roberts, P., Dowling, G., (2002), Corporate reputation and sustained superior financial performance, Strategic Management Journal, Vol.23, pp. 1077-93.

16. Sarstedt, M. Editorial Board (2009), Reputation management in times of crisis, Journal of Brand Management, 16, pp.499-503 
17. Sarstedt, M., Ringle, C. M., Schloderer, M. P. and Schwaiger, M. (2008), Accounting for Unobserved Heterogeneity in the Analysis of Antecedents and Consequences of Corporate Reputation: An Application of FIMIX-PLS, Proceedings of the 37thAnnual Conference of the European Marketing Academy, Brighton, England, 27-30 May 2008,EMAC.

18. Waddock, S. and Smith, N. (2000), Corporate responsibility audits: doing well by going good, Sloan Management Review, Vol.41 No.2, pp. 75-83.

19. Weiss, A. M., Anderson, E. And MacInnis, D. J. (1999), Reputation management as a motivation for sales structure decisions, Journal of Marketing, Vol.63,No.4,pp.74-89.

20. Williams, R. J., Barrett, J. D. (2000), Corporate philanthropy, criminal activity and firm reputation: Is there a link, Journal of Business Ethics 26, 341-350. 
NOTES 